\title{
Sanitation of a South African Forestry Nursery Contaminated with Fusarium circinatum Using Hydrogen Peroxide at Specific Oxidation Reduction Potentials
}

Schalk J. P. Van Wyk and Anne-Laure Boutigny, Department of Plant Pathology, University of Stellenbosch, Private Bag X1, Matieland 7602, South Africa; Teresa A. Coutinho, Forestry and Agricultural Biotechnology Institute, Department of Microbiology and Plant Pathology, University of Pretoria, Pretoria 0002, South Africa; and Altus Viljoen, Department of Plant Pathology, University of Stellenbosch, South Africa

\begin{abstract}
Van Wyk, S. J. P., Boutigny, A.-L., Coutinho, T. A., and Viljoen, A. 2012. Sanitation of a South African forestry nursery contaminated with Fusarium circinatum using hydrogen peroxide at specific oxidation reduction potentials. Plant Dis. 96:875-880.

Pitch canker, caused by Fusarium circinatum, was first reported in a forestry nursery in the Mpumalanga Province of South Africa in 1990, and it has since spread to almost all forestry nurseries in the country, where it causes significant economic losses. The aim of the current study was to (i) identify sources of $F$. circinatum contamination in the Karatara forestry nursery in the Western Cape Province and (ii) manage the disease by implementing an oxidation reduction potential (ORP)-based sanitation method using hydrogen peroxide. The irrigation water, planting tray inserts and seeds were screened for fungal contamination. Fusarium circinatum colonies were identified morphologically and confirmed by polymerase chain reaction using species-

served as sources of inoculum that introduced the pathogen into the nursery. The irrigation water was amended with hydrogen peroxide at an ORP level of $400 \mathrm{mV}$ for an exposure time of $6 \mathrm{~h}$ because it was observed that such a treatment effectively killed all $F$. circinatum spores and was not phytotoxic to pine seedlings under laboratory conditions. In addition, the contaminated planting tray inserts were cleaned in water amended with hydrogen peroxide at an ORP value of $360 \mathrm{mV}$ for $6 \mathrm{~h}$, which was shown to efficiently eliminate all inoculum from planting tray inserts. Since the introduction of the ORP-based sanitation method at Karatara nursery, losses of pine seedlings were reduced to insignificant levels, and field losses were minimized.
\end{abstract} specific primers. Both the irrigation water and planting tray inserts
Pitch canker of pines (Pinus spp.) is a disease caused by Fusarium circinatum Nirenberg \& O'Donnell (teleomorph: Gibberella circinata Nirenberg \& O'Donnell) (30). The disease was first discovered in the southwestern parts of the United States of America (16), and it has since been reported from Haiti (17), Japan (24), South Africa (37), Chile (39), Spain (25), Italy (7), Portugal (5), Mexico (18), and Korea (27). In forestry plantations, F. circinatum causes stem cankers and twig die-back that reduce yields, lower wood quality, and are responsible for tree mortality (38). When introduced into forestry nurseries, $F$. circinatum causes root and collar rot that result in significant losses (37). Seedlings infected in the nursery also can be symptomless and may develop the disease after they are transplanted to plantations (33).

Shoot dieback and root rot were first discovered in a South African forestry nursery in the Mpumalanga Province in 1990 (37). The causal agent, $F$. circinatum, has subsequently spread to almost all pine seedling nurseries throughout the country. The sources of introduction and dissemination of $F$. circinatum in South Africa have not been established but it is generally believed that the fungus was introduced into the country with infected seed (6) and that it spread from one nursery to another by the movement of contaminated plants and planting trays. Potential sources of dissemination within nurseries include airborne inoculum, insect vectors, and irrigation water. The pitch canker fungus currently is considered the most important constraint to pine seedling production in South Africa (40).

The first outbreak of pitch canker in a forestry plantation in South Africa occurred in Tokai near Cape Town in 2005 (9). Pinus radiata $\mathrm{D}$. Don trees grown in this plantation were obtained from

Corresponding author: A. Viljoen, E-mail: altus@sun.ac.za

Accepted for publication 12 December 2011.

http://dx.doi.org/10.1094/PDIS-05-11-0432

(C) 2012 The American Phytopathological Society the Karatara nursery near Knysna in the Western Cape Province, making this particular nursery the most likely source of inoculum (9). This hypothesis is supported by the fact that Karatara nursery was experiencing an outbreak of the disease 10 years earlier, when the trees affected at Tokai were produced. Why the disease remained undetected for 10 years is unknown but this could be attributed to Cape Town's climate, low levels of initial inoculum, absence of effective insect vectors, and lack of wounding agents (38). Since the initial report of pitch canker in Tokai, the disease has been found in pine plantations in George, Sedgefield, and Knysna in the Western Cape Province (A. Van der Hoef, personal communication).

Karatara nursery produces about 6 million pine seedlings annually. Production consists primarily of $P$. radiata plants but also includes $P$. elliottii Engelm., P. taeda L., P. tecunumanii Eguiluz and Perry, and $P$. pinaster Ait. Of these species, $P$. radiata is known to be most susceptible to the pine pitch canker fungus $(1,36)$. In 2005 and 2006, Karatara nursery lost approximately $750,000(30 \%)$ and $600,000(22 \%)$ seedlings, respectively, because of infection by $F$. circinatum. The pitch canker fungus could have been introduced into the nursery by means of infected seed, contaminated seedling trays, growth medium, or irrigation water. Because of its airborne nature, the fungus also could have entered the nursery by means of airborne inoculum that originated from adult pine trees affected by pitch canker in the vicinity of the nursery $(14,33)$. Management strategies introduced to curb seedling losses at Karatara nursery included the use of fungicides, a chlorination system to disinfest irrigation water, soaking seed in hydrogen peroxide after seed stratification, the use of freshly composted pine bark medium for $P$. radiata seedling production, lifting of planting trays off the ground surface, introducing a disease monitoring system to rogue out and destroy unhealthy seedlings, and the strict application of basic hygiene factors (A. Van der Hoef, personal communication). Although these disease management practices implemented in the nursery reduced losses of pine seedlings, the quality of seedlings produced was often compromised because mycorrhizal growth on pine roots was reduced and $F$. circinatum was not entirely eliminated from the nursery. 
Current strategies available for sanitation of irrigation water include the use of ozone and chlorine $(12,41)$. Ozone-generating plants, although very effective, are expensive to install and the maintenance costs of these plants are high (41). The use of chlorine is a common method used for sanitation of irrigation water in South Africa, and chlorine levels of 2 to $3 \mathrm{ppm}$ are effective in either reducing or eliminating $F$. circinatum in irrigation water (2). However, high levels of chlorine in the irrigation water can have detrimental effects on mycorrhizal fungi and on seedling roots that, in turn, can lead to stressed seedlings that are more susceptible to diseases (4). Chlorine also is corrosive, effective only within a narrow $\mathrm{pH}$ range, and leads to the formation of harmful chlorinated by-products $(31,42)$. An alternative to chlorine and ozone as an irrigation water disinfectant is hydrogen peroxide. Hydrogen peroxide raises the oxidation reduction potential (ORP) of the irrigation water and, in this way, eliminates pathogens that are harmful to plants and animals $(22,23,29)$.

In this study, three potential sources of inoculum at Karatara nursery were screened for the presence of $F$. circinatum. These included irrigation water, pine seed, and planting tray inserts. Irrigation water was considered a potential source of inoculum because a small pond next to the nursery was used for irrigating seedlings in the nursery. Seed were suspected as a potential source of inoculum because they were harvested from a seed orchard next to the nursery where some trees have shown symptoms of pitch canker. Seed planted in the nursery also were obtained from orchards in other locations in South Africa where no pitch canker symptoms had been observed. Pine seedlings at Karatara nursery are grown in plastic trays, each consisting of 98 removable tubelike inserts. When seedlings reach the appropriate age and physiological stage, they are transplanted to plantations. The inserts are then cleaned and reused. The cleaning process for the inserts involves removal of excess compost medium; soaking in a commercial disinfectant containing washed neutral oil, high-boiling tar acids, and methanol called Jeyes Fluid (Jeyes Professional Division Limited, Lancashire, UK); followed by drying. The plant inserts, in which individual pine seedlings are planted, were considered a potential source of $F$. circinatum inoculum because these inserts are reused. The planting medium, composted pine bark, was not considered a potential source of inoculum because fresh medium is obtained from pitch canker-free areas in South Africa, and because the medium is not reused. Composted pine bark medium also often has disease-suppressive properties resulting from colonization by beneficial microbes (19).

The current study was initiated to identify sources of $F$. circinatum that affect pine seedlings in the Karatara nursery. Once identified, an attempt was made to eradicate these sources in an affordable, effective, and environmentally sound way. Despite the limited information available for the use of ORP-based methods involving hydrogen peroxide for the elimination of plant pathogens (29), hydrogen peroxide was tested as a sanitizing agent to disinfect irrigation water and planting tray inserts at the Karatara nursery. Different ORP levels and exposure times were optimized to ensure elimination of $F$. circinatum without causing damage to pine seedlings.

\section{Materials and Methods}

Identification of sources of inoculum. Irrigation water. The pine seedlings produced in Karatara nursery obtain irrigation water from a medium-size pond (approximately $60 \mathrm{~m}$ long by $40 \mathrm{~m}$ wide by $5 \mathrm{~m}$ deep) that is situated $50 \mathrm{~m}$ away from the nursery on the boundary of a pine plantation. From the pond, water is being pumped into two reservoirs built in series: the first reservoir has a diameter of $8.1 \mathrm{~m}$ and a height of $1.6 \mathrm{~m}$ and the second reservoir has a diameter of $10 \mathrm{~m}$ and is $2.2 \mathrm{~m}$ deep. Water is sprayed from the second reservoir onto the seedlings in the nursery. At the time of the first collection to identify sources of inoculum, calcium hypochlorite was added between the first and the second reservoir to elevate the concentration in the second reservoir to $5 \mathrm{ppm}$. Ten samples, each consisting of 1 liter of water, were collected from each of the four points in the irrigation system, including the pond, the first reservoir, the second reservoir, and at a single irrigation point in the nursery. Water samples were then filtered through sterile Whatman number 1 filter papers (Whatman, South Africa) using a vacuum pump assembly (Picolino, South Africa). Each filter paper was placed for $10 \mathrm{~s}$ onto Fusarium-selective agar (FSA; 33) in order to transfer Fusarium spores. After 5 to 7 days of incubation, suspected Fusarium colonies were subcultured onto potato dextrose agar (PDA) plates, single-spored, and incubated for 10 days on PDA and carnation leaf agar (CLA) plates for morphological identification (28). If identities were uncertain, identification was confirmed using molecular techniques as described below.

Seed. In a first screening, seed samples representing all Pinus spp. grown at Karatara nursery, including $P$. tecunumanii, $P$. elliottii, $P$. taeda, $P$. pinaster, and $P$. radiata, first and second generation, were tested for contamination with $F$. circinatum. $P$. radiata second-generation is the open-pollinated progeny of first-generation $P$. radiata plants that are produced in an effort to improve growth characteristics in the species. Of each batch, 50 untreated and 50 surface-sterilized seeds were placed directly onto PDA plates containing neomycin $(0.12 \mathrm{~g} / \mathrm{liter})$, with five seeds per petri dish. Surface sterilization was accomplished by dipping seed in $70 \%$ ethanol for $1 \mathrm{~min}$, then in $3 \%$ sodium hypochlorite for $3 \mathrm{~min}$, and then washing them three times in sterile distilled water (26). In addition, the seed coats of another 50 seeds of each batch were removed and the endosperm and embryo were placed on PDA. In a second screening, 500 untreated and 500 surface-sterilized $P$. radiata firstand second-generation seeds from the same batches were tested further as described above. Fusarium colonies that developed from any of the seed were subcultured, single spored, and identified to species.

Seedling tray inserts. Tray inserts were collected from the nursery for testing for contamination with $F$. circinatum. During the first collection, dirty tray inserts were cleaned by nursery employees for reuse by removing excess soil residues present on the inside of inserts and washing with Jeyes Fluid, which is a treatment implemented by the nursery personnel. Fifty seedling tray inserts each were randomly selected before and after they were cleaned. Soil residues that remained on the inside of the inserts after cleaning were scraped off and collected in bottles containing $5 \mathrm{ml}$ of sterile water, and subsequently plated on FSA for identification of F. circinatum.

Molecular identification of $\boldsymbol{F}$. circinatum. For molecular identification, approximately $100 \mathrm{mg}$ of fresh mycelia was scraped from the PDA plates with single-spored colonies and transferred to 1.5-ml microtubes. DNA was then extracted using the Wizard SV genomic DNA purification system (Promega, South Africa). The pitch canker pathogen was identified by using species-specific primers CIRC1A and CIRC4A for $F$. circinatum (33). The polymerase chain reaction (PCR) mixture contained $13.5 \mu$ of $\mathrm{H}_{2} \mathrm{O}, 2.5$ $\mu \mathrm{l}$ of $10 \times$ PCR buffer, $2.0 \mu \mathrm{l}$ of $50 \mathrm{mM} \mathrm{MgCl} 2,0.8 \mu \mathrm{l}$ of deoxynucleoside mixture $(10 \mathrm{mM}), 0.5 \mu \mathrm{l}$ of each primer $(50 \mathrm{mM}), 0.2 \mu \mathrm{l}$ of Platinum Taq DNA polymerase (Invitrogen, South Africa), and 5 $\mu \mathrm{l}$ of template DNA (corresponding to approximately $250 \mathrm{ng}$ of DNA). PCR amplification consisted of an initial step at $94.0^{\circ} \mathrm{C}$ for $3 \mathrm{~min}$; followed by 45 cycles of $94^{\circ} \mathrm{C}$ for $35 \mathrm{~s}, 68^{\circ} \mathrm{C}$ for $55 \mathrm{~s}$, and $72^{\circ} \mathrm{C}$ for $50 \mathrm{~s}$; with a final extension step at $72^{\circ} \mathrm{C}$ for $12 \mathrm{~min}$. Resulting PCR products were separated by gel electrophoresis, and the gels were stained with ethidium bromide and visualized under UV lights. The F. circinatum isolate FCC 3577 (obtained from the Forestry and Agricultural Biotechnology Institute, University of Pretoria, Pretoria, South Africa) was used as a positive control.

Effect of hydrogen peroxide at different ORP levels and different exposure times on $\boldsymbol{F}$. circinatum. $F$. circinatum (reference isolate FCC 3577) was grown on PDA plates for 14 days at $25^{\circ} \mathrm{C}$. A spore suspension was prepared from these plates by adding $2 \mathrm{ml}$ of sterile distilled water to each plate and gently loosening the fungal spores with a bent glass rod. The spore suspension was then filtered through four layers of cheese cloth to remove pieces of 
mycelium and agar. The final spore concentration was determined with a Bright-Line hemacytometer (Boeco, South Africa) and adjusted to $10^{7}$ spores $/ \mathrm{ml}$.

To prepare water with a range of ORP levels, six 500-ml glass beakers containing $200 \mathrm{ml}$ of deionized sterile water were placed on a magnetic stirrer. The control did not receive any hydrogen peroxide and had a final ORP level of $180 \mathrm{mV}$ as measured with a handheld ORP meter (Hanna Instruments, South Africa). The ORP of the water in the other five beakers was adjusted by adding hydrogen peroxide (Hyprox 500; Protea Chemicals, South Africa) in order to raise ORP levels to $300,350,400,450$, and $500 \mathrm{mV}$. The beakers were then left in the laboratory at room temperature, and the ORP was again measured 6 and $24 \mathrm{~h}$ after the ORP values had been set.

In order to test the effect of the different ORP levels on $F$. circinatum at different exposure times, $20 \mathrm{ml}$ of the F. circinatum spore suspension were added to $180 \mathrm{ml}$ of water representing each of the six different ORP values to obtain a final spore concentration of $10^{6} \mathrm{spores} / \mathrm{ml}$. After exposing the spore suspensions to the different ORP levels for time periods of $30 \mathrm{~s}, 5 \mathrm{~min}, 30 \mathrm{~min}, 2 \mathrm{~h}, 6 \mathrm{~h}$, and 24 h, survival of $F$. circinatum spores was determined. Samples $(1 \mathrm{ml})$ were taken for the each ORP value from the same container at the different time points, and a 10 -fold dilution series was prepared in sterile distilled water ranging from $10^{5}$ to $10^{1}$ spores $/ \mathrm{ml}$. A $1-\mathrm{ml}$ subsample for each ORP level and time point were then transferred to PDA plates, with five plates used for each dilution point. The plates were then incubated at $25^{\circ} \mathrm{C}$ and the average number of $\mathrm{CFU}$ per milliliter of water of each ORP value and at each time point was calculated after 3 days. The experiment was conducted twice.

Phytotoxicity of hydrogen peroxide-amended water to $P$. $r a$ diata seedlings. Healthy 6 -month-old $P$. radiata seedlings were irrigated daily for 30 days with hydrogen peroxide-amended water at ORP values of 300,350, 400, 450, and $500 \mathrm{mV}$. The control treatment consisted of seedlings that were given water without hydrogen peroxide added (ORP value of $180 \mathrm{mV}$ ). The seedlings were arranged in a randomized block design with four replications and 14 seedlings per replicate and, after treatment, they were monitored daily for phytotoxicity. Seedling mortality was documented for 30 days.

Treatment and elimination of sources of inoculum. Irrigation water. At the time of the second collection, a hydrogen peroxide treatment had been implemented to treat the irrigation water. Hydrogen peroxide was added to the irrigation water in one of the reservoirs at Karatara nursery to raise the ORP level to $400 \mathrm{mV}$ and was retained in the reservoir for at least $6 \mathrm{~h}$ before it was released. When the water was used to irrigate the seedlings in the nursery, the ORP level had dropped to $340 \mathrm{mV}$. Twelve samples, consisting of $500 \mathrm{ml}$ of water each, were collected from each sampling point, which included the pond, one of the reservoirs, and at a single irrigation point in the nursery. Irrigation water was then tested for the presence of $F$. circinatum as described above.

Seedling tray inserts. During the second collection, planting tray inserts were collected from Karatara nursery after the cleaning process was modified by replacing the commercial disinfectant with an ORP treatment using hydrogen peroxide. Planting tray inserts were cleaned by the nursery personnel by removing all the debris and growth medium from them and soaking them in water amended with hydrogen peroxide with an ORP value of $360 \mathrm{mV}$ for $6 \mathrm{~h}$. Inserts were then dried and tested for the presence of $F$. circinatum as described above. Fifty seedling tray inserts were randomly selected before and after the cleaning process, $F$. circinatum was identified, and the effectiveness of the ORP treatment determined.

Statistical analysis. One-way analysis of variance and Fischer's least significant difference (LSD) $(P=0.05)$ were used to compare the number of CFU found at the different points in the Karatara nursery irrigation system; the number of CFU that survived the different ORP levels and exposure times in the laboratory study; and the number of healthy, wilted, and dead 6-month-old seedlings after being irrigated with hydrogen peroxide-amended water. Fischer's LSD post-hoc test was used to calculate significant differences between the number of CFU at different points in the irrigation system, exposure time, and ORP level treatment combinations, and the effect of irrigating 6-month-old seedlings with water with different ORP levels. A 5\% significant level was used as a guideline.

\section{Results}

Sources of inoculum. Irrigation water. During the first inspection for contamination of irrigation water at Karatara nursery, the average number of $F$. circinatum (CFU per liter of water) from the pond and from the untreated reservoir (reservoir 1) did not differ significantly (Table 1). When the water in the second reservoir (reservoir 2) was treated with chlorine, the average number of $F$. circinatum propagules in reservoir 2 and in the nursery was significantly reduced. However, the pathogen was not entirely eliminated from the water and $F$. circinatum could still be isolated at a rate of 1.3 CFU/liter of water in the nursery.

Seed. In the first screening, seed of $P$. tecunumanii, $P$. elliottii, $P$. taeda, and $P$. pinaster tested negative for the presence of $F$. circinatum whereas, for $P$. radiata, $32 \%$ of the seed of the first generation and $22 \%$ of the seed of the second generation were contaminated. In the first- and second-generation batches, contamination decreased to 6 and 14\%, respectively, following surface sterilization. F. circinatum was only isolated from the embryos and endosperm from the $P$. radiata first generation seed at a rate of $14 \%$. In the second screening, seed from the contaminated first- and second-generation batches tested negative for the presence of the pitch canker fungus, whether treated or not treated with surface disinfectants (data not shown).

Seedling tray inserts. When first tested, $30 \%$ of planting tray inserts were found to be contaminated with $F$. circinatum before cleaning and disinfestation. After the inserts were cleaned and disinfested with Jeyes fluid, $18 \%$ were still contaminated with $F$. circinatum.

Effect of hydrogen peroxide on $\boldsymbol{F}$. circinatum. Supplementation of water with hydrogen peroxide at certain ORP levels significantly affected the survival of $F$. circinatum spores (Fig. 1). At ORP values of $300 \mathrm{mV}, 33 \%$ of fungal spores survived after an exposure time of $24 \mathrm{~h}$. However, for shorter exposure times, there were no significant differences between the $300 \mathrm{mV}$ treatment and the control group (180 $\mathrm{mV}$ treatment). In all, $14 \%$ of fungal spores survived an exposure time of $6 \mathrm{~h}$ at an ORP value of $350 \mathrm{mV}$. Less than $5 \%$ of fungal spores survived after an exposure time of $30 \mathrm{~min}$ $(450 \mathrm{mV}), 2 \mathrm{~h}(400 \mathrm{mV})$, and $24 \mathrm{~h}(350 \mathrm{mV})$. The following treatments killed all $F$. circinatum spores: $400 \mathrm{mV}$ for exposure times of $6 \mathrm{~h}$ and $24 \mathrm{~h} ; 450 \mathrm{mV}$ for exposure times of 2, 6, and $24 \mathrm{~h}$; and $500 \mathrm{mV}$ for all exposure times.

After supplementation of hydrogen peroxide to water, ORP levels were monitored after 6 and $24 \mathrm{~h}$ (Table 2). Some of the ORP levels decreased over time. The 400- and 450-mV treatments decreased by 6 and $11.3 \%$, respectively, after $6 \mathrm{~h}$ but showed no decrease from 6 to $24 \mathrm{~h}$. The $500-\mathrm{mV}$ treatment decreased by $5.4 \%$ after $6 \mathrm{~h}$ and by $15.4 \%$ after $24 \mathrm{~h}$.

Table 1. Presence of Fusarium circinatum in irrigation water at the Karatara nursery during chlorine or hydrogen peroxide treatment

\begin{tabular}{lcc}
\hline & \multicolumn{2}{c}{ Treatment applied $^{\mathbf{x}}$} \\
\cline { 2 - 3 } Source & Chlorine $^{\mathbf{y}}$ & Hydrogen peroxide $^{\mathbf{z}}$ \\
\hline Pond & $5.9 \mathrm{a}$ & $3.2 \mathrm{~b}$ \\
Reservoir 1 & $6.4 \mathrm{a}$ & $0 \mathrm{~d}$ \\
Reservoir 2 & $1.6 \mathrm{c}$ & $\ldots$ \\
Nursery & $1.3 \mathrm{c}$ & $0 \mathrm{~d}$ \\
\hline
\end{tabular}

${ }^{\mathrm{x}}$ Results are expressed as the average number of CFU per liter of water Numbers followed by the same letter within columns are not significantly different from each other $(P=0.01)$.

${ }^{y}$ Calcium hypochlorite added at $5 \mathrm{ppm}$ in reservoir 2 at Karatara nursery.

${ }^{\mathrm{z}}$ Hydrogen peroxide added in reservoir 1 at Karatara nursery to an oxidation reduction potential of $400 \mathrm{mV}$. 
Phytotoxicity of hydrogen peroxide-amended water to $P$. $r a$ diata seedlings. Six-month-old $P$. radiata seedlings were significantly affected by hydrogen peroxide-amended water (Table 3 ). For the control treatment $(180 \mathrm{mV}), 92.9 \%$ of plants remained healthy without any signs of phytotoxicity or wilting symptoms throughout the trial. In contrast, all seedlings irrigated with water with an ORP of $500 \mathrm{mV}$ were dead within 30 days. Most $(89.3 \%)$ of the seedlings were killed when irrigated with water with an ORP of $450 \mathrm{mV}$. After 30 days of irrigation, there were no significant differences in the number of dead, wilted, and healthy seedlings between the control treatment $(180 \mathrm{mV})$ and the $300-$, $350-$, and $400-\mathrm{mV}$ treatments. In addition, none of the plants irrigated with water with these ORP values showed signs of browning or chemically burned needles. Although the differences were not significant, seedlings died in the $350-$ and $400-\mathrm{mV}$ treatments.

Treatment and elimination of sources of inoculum in Karatara nursery. To disinfest the irrigation water at Karatara nursery, hydrogen peroxide was added to an ORP value of $400 \mathrm{mV}$ and it was retained for $6 \mathrm{~h}$ in the reservoirs. These conditions were chosen based on the results obtained under laboratory conditions, showing that this treatment was not phytotoxic for the seedlings (Table 3) and that a treatment of $400 \mathrm{mV}$ for an exposure time of 6 h was sufficient to kill all $F$. circinatum spores (Fig. 1). This treatment completely eliminated $F$. circinatum from the irrigation water in both the reservoirs and the nursery (Table 1), showing that the treatment implemented in this study was very effective in sanitizing irrigation water.

We modified the cleaning process of the planting tray inserts by cleaning them in water supplemented with hydrogen peroxide at an ORP value of $360 \mathrm{mV}$ for an exposure time of $6 \mathrm{~h}$. In all, $18 \%$ of the inserts before cleaning were contaminated with $F$. circinatum while none of the inserts after cleaning were contaminated, showing that the cleaning process implemented in this study was very efficient in sanitizing seedling tray inserts.

In addition, no phytotoxicity was observed in the nursery, and establishment of mycorrhizae on $P$. radiata roots and root health returned to normal, based on visual observation, compared with the severe damage observed to pine roots and the detrimental effects on mycorrhizae following chlorine treatment of the irrigation water that was used previously to this study in the nursery.

Clean irrigation water in combination with $F$. circinatum-free planting tray inserts reduced losses in the nursery to insignificant levels, and losses of pine seedlings after field transplanting were minimized by 2008 (Table 4). This is in contrast to the substantial losses experienced in the nursery in 2003, 2004, 2005, 2006, and 2007 (Table 4).

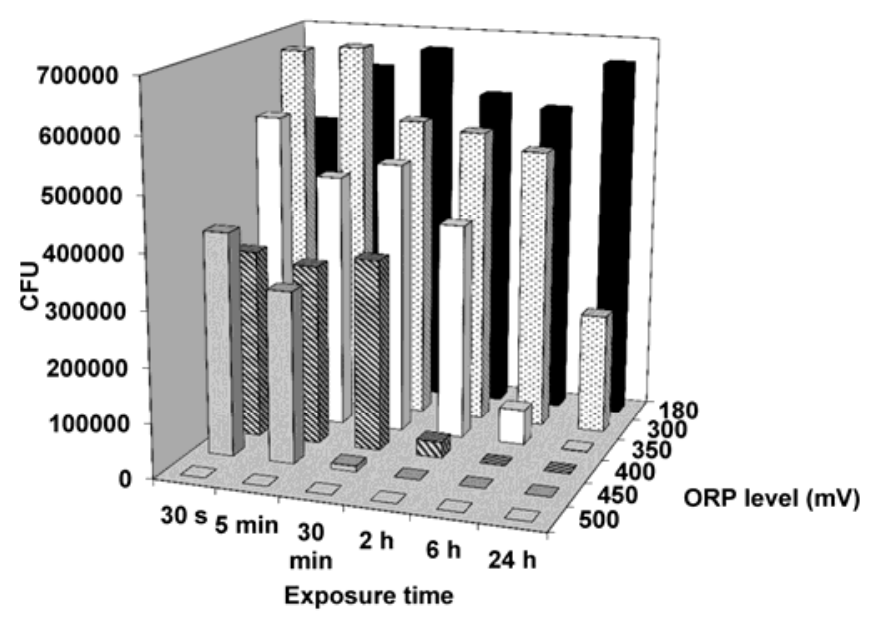

Fig. 1. Effect of different oxidation reduction potentials (ORPs) and exposure times on the survival of spores of Fusarium circinatum. Mean values were calculated for the average number of CFU from six plates per treatment.

\section{Discussion}

The first introduction of $F$. circinatum into a South African forestry nursery approximately two decades ago left the local forestry industry with a significant challenge: eradicate the pathogen from this nursery or face the possible spread of the fungus to other nurseries and forestry plantations with highly susceptible Pinus spp. (37). The pathogen was not eradicated and has since spread to almost all forestry nurseries in the country and, recently, to plantations, presumably because of the movement of infected planting material and equipment between nurseries and into plantations (9). In this study, $F$. circinatum contamination was reduced to insignificant levels in a forestry nursery that was severely affected by the pitch canker fungus. The reduction in disease incidence was the result of a relatively simple strategy: identification of the primary sources of inoculum and elimination of these sources with a sanitation process that is effective, affordable, and environmentally sound.

The irrigation water and planting tray inserts served as important sources of inoculum of $F$. circinatum in Karatara nursery. Despite treatment with chlorine and other disinfectants tested in the Karatara nursery, the pitch canker pathogen was never eliminated from the water and tray inserts and could, therefore, serve as inoculum to infect healthy pine seedlings. In addition, chlorine treatment severely damaged roots and mycorrhizae. By supplementing irrigation water with hydrogen peroxide to raise the ORP level to 400 $\mathrm{mV}$ for $6 \mathrm{~h}, F$. circinatum was successfully eliminated from irrigation water without damaging the seedlings. In fact, this treatment resulted in normal establishment of mycorrhizae, which may have contributed to the successful establishment of nursery plants in the field, even under conditions of severe drought stress (unpublished). Hydrogen peroxide-amended water also was successfully used to eliminate the pathogen from contaminated planting tray inserts when an ORP of $360 \mathrm{mV}$ was used for $6 \mathrm{~h}$. Because the inserts were allowed to dry before planting, this level of ORP did not have any negative effect on newly planted seedlings.

Table 2. Changes in oxidation reduction potential (ORP) of hydrogen peroxide-amended water over time

\begin{tabular}{lcc}
\hline & \multicolumn{2}{c}{ ORP level $(\mathbf{m V})$} \\
\cline { 2 - 3 } Original ORP level $(\mathbf{m V})^{\mathbf{z}}$ & After $\mathbf{6 ~ h}$ & After $\mathbf{2 4} \mathbf{~}$ \\
\hline Nontreated & 183 & 231 \\
300 & 302 & 316 \\
350 & 344 & 339 \\
400 & 376 & 375 \\
450 & 399 & 401 \\
500 & 473 & 423 \\
\hline
\end{tabular}

${ }^{\mathrm{z}}$ Nontreated water did not receive any hydrogen peroxide and had a final ORP level of $180 \mathrm{mV}$ as measured with a handheld ORP meter. The ORP of the water in the other five beakers was adjusted by adding hydrogen peroxide in order to raise ORP levels to $300,350,400,450$, and $500 \mathrm{mV}$. The beakers were then left in the laboratory at room temperature, and the ORP was again measured 6 and $24 \mathrm{~h}$ after the ORP values had been set.

Table 3. Phytotoxicity of seedlings of Pinus radiata following seed treatment with hydrogen peroxide-amended water at different oxidation reduction potentials (ORPs) after 30 days

\begin{tabular}{lccc}
\hline & \multicolumn{3}{c}{ Incidence on seedlings $(\%)^{\mathbf{y}}$} \\
\cline { 2 - 4 } ORP level $(\mathbf{m V})^{\mathbf{z}}$ & Dead & Wilted & Healthy \\
\hline Nontreated water & $0 \mathrm{c}$ & $5.4 \mathrm{a}$ & $92.9 \mathrm{a}$ \\
300 & $0 \mathrm{c}$ & $7.1 \mathrm{a}$ & $92.9 \mathrm{a}$ \\
350 & $8.9 \mathrm{c}$ & $0 \mathrm{a}$ & $91.1 \mathrm{a}$ \\
400 & $1.8 \mathrm{c}$ & $3.6 \mathrm{a}$ & $92.9 \mathrm{a}$ \\
450 & $89.3 \mathrm{~b}$ & $5.4 \mathrm{a}$ & $5.3 \mathrm{~b}$ \\
500 & $100 \mathrm{a}$ & $0 \mathrm{a}$ & $0 \mathrm{~b}$ \\
\hline
\end{tabular}

${ }^{y}$ Numbers followed by the same letter are not significantly different from each other $(P=0.01)$

${ }^{\mathrm{z}}$ Nontreated water did not receive any hydrogen peroxide and had a final ORP level of $180 \mathrm{mV}$. 
The two seed batches ( $P$. radiata first and $P$. radiata second generation) investigated in this study initially tested positive for the presence of $F$. circinatum. Because surface sterilization substantially reduced the number of contaminated seed, $F$. circinatum is believed to be more commonly found on the seed surface than inside the seed coat or the endosperm or embryo. Spores of $F$. circinatum on the seed coat are known to be the result of the deposition of airborne spores $(34,35)$. Why no contamination was found when these seed batches were again tested 7 months later is unknown. Although surface disinfestation of $P$. radiata seed from infested seed orchards near Karatara nursery may reduce or destroy $F$. circinatum, it is advised that seed from orchards free of pitch canker be used for planting in the nursery because it is known that affected orchards may be a source of seed contamination (10).

ORP-based methods have been successfully used to kill deleterious microorganisms in different food-processing environments. For instance, chlorine dioxide has been used to adjust the ORP level of water to treat Salmonella spp. on alfalfa seed and sprouts (22), and the use of chlorine, bromine, ozone, sodium, calcium hypochlorite, or hydrogen peroxide has been proposed for the elimination of Pythium spp. from irrigation water (29). Hydrogen peroxide has previously been used for the disinfestation of human pathogens such as Escherichia coli and Salmonella spp. (23). The current study, to our knowledge, is the first report on the use of hydrogen peroxide and ORP to disinfest irrigation water and plant inserts in a nursery environment.

The use of hydrogen peroxide to raise the ORP of water provides an efficient, affordable, and safe option for nursery sanitation. Hydrogen peroxide is less expensive than chlorine and measuring the ORP of irrigation water is a simple procedure that can easily be done using a handheld device. Furthermore, ORP is not affected by $\mathrm{pH}$ and measures the activity of the specific disinfectant being used without interacting with the water constituents (29). The chemical is noncorrosive and is rapidly broken down to harmless water and oxygen $(13,32)$. The irrigation system at Karatara nursery has the required design for the use of hydrogen peroxide to alter the ORP of the water, in that water can be treated in a reservoir before it is sprayed onto the seedlings. Apart from its antimicrobial properties, hydrogen peroxide is known to induce plant defense responses (21).

The elimination of the pitch canker fungus in the Karatara nursery cannot be attributed only to the introduction of ORP treatment for sanitation purposes but also may involve other integrated disease management strategies implemented over time. The improvement of nursery hygiene and the treatment of fungal gnats and their larvae that can act as potential vectors of $F$. circinatum, or as wounding agents, might have contributed to the lower disease incidence. Recovery of the seedling root systems and recolonization by mycorrhizal fungi after the termination of the chlorine treatment of water also may have contributed to better protection against plant pathogens and better survival during field planting $(3,8)$. A more in-depth study is required to investigate aerial inoculum and the role it plays in the contamination of Pinus seedlings in the nursery. Spores could originate from within the nursery itself or they could come from plantations in the surrounding area, where the pitch canker fungus is known to be active. Therefore, a strategy whereby all seedlings and trees with pitch canker symptoms in the vicinity of the nursery should be removed must be considered. There may also be multiple means by which the pathogen survives; for instance, in or on dead plant material and contaminated soil debris in or around the nursery $(11,15)$. The source of the water contamination also should be determined. It is possible that spores were blown into the pond that serves as the main water source to the nursery or into the Karatara River, from which water is pumped into the pond. The Karatara River flows through a forestry area where pine pitch canker is known to occur.

The first step in preventing the widespread introduction of $F$. circinatum into forestry plantations in South Africa will be to eliminate the pathogen from all forestry nurseries in South Africa. This can be achieved by proper sanitation practices and the use of clean seed, water, soil, and planting pots. In this regard, the findings of the current study can make a major contribution to managing the pitch canker fungus in South Africa and elsewhere. In addition, nurseries should neither be near infected trees nor use seed coming from infected trees. The role of fungus gnats in the etiology of the disease should be elucidated, and the insects should be controlled (20). Finally, all Pinus spp. grown in South Africa, as well as clonal families and hybrids, should be screened for resistance to $F$. circinatum.

\section{Literature Cited}

1. Aegerter, B. J., and Gordon, T. R. 2006. Rates of pitch canker induced seedling mortality among Pinus radiata families varying in levels of genetic resistance to Gibberella circinata (anamorph Fusarium circinatum). For. Ecol. Manage. 235:14-17.

2. Anonymous, 2002. Fusarium circinatum in pine nurseries: A guide to appropriate management strategies. Tree Protective Corporate Program pamphlet. Forestry and Agricultural Biotechnology Institute (FABI). http://www.up.ac.za/academic/fabi/tpcp/pamphlets/fusarium.

3. Azcon-Aguilar, C., and Barea, J. M. 1996. Arbuscular mycorrhizas and biological control of soil-borne plant pathogens-an overview of the mechanisms involved. Mycorrhiza 6:457-464.

4. Blakeslee, G. M., Dorset, R. D., and Oak, S. W. 1979. Inoculum dispersal of the pine pitch canker fungus (Fusarium moniliforme var. subglutinans).

Table 4. Losses of Pinus radiata seedlings in Karatara nursery from 2003 to 2010

\begin{tabular}{|c|c|c|c|c|}
\hline \multirow[b]{2}{*}{ Year } & \multicolumn{3}{|c|}{ P. radiate seedlings ${ }^{\mathrm{z}}$} & \multirow[b]{2}{*}{ Remarks } \\
\hline & Planted & Died & Death $(\%)$ & \\
\hline 2003 & $1,576,428$ & 370,266 & 23.5 & Mortality in 2003 attributed to poor seed germination. No action taken. \\
\hline 2004 & $2,279,627$ & 415,170 & 18.2 & Mortality in 2004 attributed to poor seed germination. No action taken. \\
\hline 2005 & $2,543,792$ & 751,650 & 29.5 & $\begin{array}{l}\text { Mortality in } 2005 \text { resulted in investigation. Causal agent identified a } F \text {. circinatum. } \\
\text { Nursery hygiene upgraded; chlorine introduced as water treatment. Very high field mortality. }\end{array}$ \\
\hline 2006 & $2,711,384$ & 595,640 & 22.0 & $\begin{array}{l}\text { Continued high mortality in } 2006 \text { resulted in further investigation. Nursery hygiene was upgraded, } \\
\text { and chlorine concentration increased. Additional investigation on role of fungal gnats. Complaints } \\
\text { about field mortality by growers. }\end{array}$ \\
\hline 2007 & 298,400 & 75,950 & 25.5 & $\begin{array}{l}\text { High mortality rate in } 2007 \text { still contributed to } F \text {. circinatum. } P \text {. radiata replaced by } P \text {. elliottii in } \\
\text { nursery. War on fungal gnats. Complaints about field mortality. }\end{array}$ \\
\hline 2008 & $2,900,366$ & Insig. & 0 & $\begin{array}{l}\text { Fewer losses of seedlings in } 2008 \text { due to chlorine treatment and growing of } P \text {. elliottii seedlings. } \\
\text { Clients are happier with seedlings, but a significant reduction of mycorrhizae on roots. } \\
\text { First report of pitch canker in plantations. }\end{array}$ \\
\hline 2009 & $3,038,338$ & Insig. & 0 & $\begin{array}{l}\text { Change chlorine treatment to ozone and peroxide. Losses of } P \text {. radiata seedlings very low in } 2009 \text {. } \\
\text { Field losses less than } 2 \% \text {. Clients happy with seedlings. }\end{array}$ \\
\hline 2010 & $2,596,164$ & Insig. & 0 & $\begin{array}{l}\text { ORP treatment optimized in } 2010 \text {. Very few losses of } P \text {. radiata in nursery. } \\
\text { Clients extremely happy with almost no losses in field, despite severe drought. } \\
\text { Significant increase of mycorrhizae on roots. }\end{array}$ \\
\hline
\end{tabular}

\footnotetext{
${ }^{\mathrm{z}}$ Notes provided by nurserymen at Karatara nursery, South Africa. Insig. = insignificant losses, indicating that losses were considered by nurserymen to be too few to document.
} 
Phytopathology 69:1022-1022.

5. Bragança, H., Diogo, E., Moniz, F., and Amaro, P. 2009. First report of pitch canker on pines caused by Fusarium circinatum in Portugal. Plant Dis. 93:1079-1079.

6. Britz, H., Coutinho, T. A., Gordon, T. R., and Wingfield, M. J. 2001. Characterization of the pitch canker fungus, Fusarium circinatum, from Mexico. S. Afr. J. Bot. 67:609-614.

7. Carlucci, A., Colatruglio, L., and Frisullo, S. 2007. First report of pitch canker caused by Fusarium circinatum on Pinus halepensis and P. pinea in Apulia (Southern Italy). Plant Dis. 91:1683-1683.

8. Carpio, L. A., Davies, F. T., and Arnold, M. A. 2003. Effect of commercial arbuscular mycorrhizal fungi on growth, survivability, and subsequent landscape performance of selected container grown nursery crops. J. Environ. Hortic. 21:190-195.

9. Coutinho, T. A., Steenkamp, E. T., Mongwaketsi, K., Wilmot, M., and Wingfield, M. J. 2007. First outbreak of pitch canker in a South African pine plantation. Australas. Plant Pathol. 36:256-261.

10. Dwinell, L. D. 1999. Contamination of Pinus radiata seeds in California by Fusarium circinatum. In: Annu. Int. Res. Conf. Methyl Bromide Alternatives and Emissions Reductions. San Diego, CA.

11. Dwinell, L. D., and Barrows, J. B. 1978. Recovery of the pine pitch canker fungus from pine plantation and seed orchard soil. Phytopathol. News 12:207.

12. Elmer, W. H. 2008. Preventing spread of Fusarium wilt of Hiemalis begonias in the greenhouse. Crop Prot. 27:1078-1083.

13. Fonseca, J. M. 2006. Postharvest handling and processing: sources of microorganisms and impact of sanitizing procedures. Pages 85-120 in: Microbiology of Fresh Produce. K. R. Matthews, ed. ASM Press, Washington, DC.

14. Garbelotto, M., Smith, T., and Schweigkofler, W. 2008. Variation in rates of spore deposition of Fusarium circinatum, the causal agent of pine pitch canker, over a 12-month-period at two locations in Northern California. Phytopathology 98:137-143.

15. Gordon, T. R., Storer, A. J., and Wood, D. L. 2001. The pitch canker epidemic in California. Plant Dis. 85:1128-1139.

16. Hepting, G. H., and Roth, E. R. 1946. Pitch canker, a new disease of some southern pines. J. For. 44:724-744.

17. Hepting, G. H., and Roth, E. R. 1953. Host relations and spread of the pine pitch canker disease. Phytopathology 43:475-475.

18. Hodge, G. R., and Dvorak, E. W. S. 2007. Variation in pitch canker resistance among provenances of Pinus patula and Pinus tecunumanii from Mexico and Central America. New For. 33:193-206.

19. Hoitink, H. A. J., and Fahy, P. C. 1986. Basis for the control of soilborne plant pathogens with composts. Annu. Rev. Phytopathol. 24:93-114.

20. Hurley, B. P., Govender P., Coutinho T. A., Wingfield, B. D., and Wingfield, M. J. 2007. Fungus gnats and other Diptera in South African forestry nurseries and their possible association with the pitch canker fungus. S. Afr. J. Sci. 103:43-46.

21. Kawano, T. 2003. Roles of the reactive oxygen species-generating peroxidase reactions in plant defense and growth induction. Plant Cell Rep. 21:829-837.

22. Kim, C., Hung, Y., and Brackett, R. E. 2000. Roles of oxidation-reduction potential in electrolyzed oxidizing and chemically modified water for the inactivation of food-related pathogens. J. Food Prot. 63:19-24.

23. Kim, C., Hung, Y., Brackett, R., and Lin, C. 2003. Efficacy of electrolyzed oxidizing water in inactivating Salmonella on alfalfa seeds and sprouts. J. Food Prot. 66:208-214.

24. Kobayashi, T., and Muramoto, M. 1989. Pitch canker of Pinus luchuensis, a new disease of Japanese forests. For. Pests 40:169-173.

25. Landeras, E., García, P., Fernández-Alonso, Y., and Braña, M. 2005. Outbreak of pitch canker caused by Fusarium circinatum on Pinus spp. in Northern Spain. Plant Dis. 89:1015-1015.

26. Larran, S., Perello, A., Simo, M. R., and Moreno, V. 2002. Isolation and analysis of endophytic microorganisms in wheat (Triticum aestivum L.) leaves. World J. Microbiol. Biotechnol. 18:683-686.

27. Lee, J. K., Lee, S. H., Yang, S. I., and Lee, Y. W. 2000. First report of pitch canker disease on Pinus rigida in Korea. Plant Pathol. J. 16:52-54.

28. Leslie, J. F., and Summerell, B. A. 2006. The Fusarium Laboratory Manual Blackwell Publishing Ltd., Oxford.

29. Newman, S. E. 2004. Disinfecting irrigation water for disease management. In: Proc. 20th Annu. Conf. Pest Manage. Ornamentals. Soc. Am. Florists. San Jose, CA.

30. Nirenberg, H. I., and O'Donnell, K. 1998. New Fusarium species and combinations within the Gibberella fujikuroi species complex. Mycologia 90:434-458.

31. Roberts, R. G., and Reymond, S. T. 1994. Chlorine dioxide for reduction of postharvest pathogen inoculums during handling of fruit tree fruits. Appl. Environ. Microbiol. 60:2864-2868.

32. Sapers, G. M., 2001. Efficacy of washing and sanitizing methods for disinfection of fresh fruit and vegetable products. Food Technol. Biotechnol. 39:305-311.

33. Schweigkofler, W., O'Donnell, K., and Garbelotto, M. 2004. Detection and quantification of airborne conidia of Fusarium circinatum, the causal agent of pine pitch canker, from two California sites by using a real-time PCR approach combined with a simple spore trapping method. Appl. Environ. Microbiol. 70:3512-3520.

34. Storer, A. J., Gordon, T. R., and Clark, S. L. 1998. Association of the pitch canker fungus, Fusarium subglutinans f. sp. pini with Monterey pine seeds and seedlings in California. Plant Pathol. 47:649-656.

35. Storer, A. J., Wood, D. L., Wikler, K. R., and Gordon, T. R. 1998. Association between a native spittlebug (Homoptera: Cercopidae) on Monterey pine and an introduced tree pathogen which causes pitch canker disease. Can. Entomol. 130:783-792.

36. Viljoen, A., Wingfield, M. J., Kemp, G. H. J., and Marasas, W. F. O. 1995. Susceptibility of pines in South Africa to the pitch canker fungus Fusarium subglutinans f. sp. pini. Plant Pathol. 44:877-882.

37. Viljoen, A., Wingfield, M. J., and Marasas., W. F. O. 1994. First report of Fusarium subglutinans f. sp. pini on pine seedlings in South Africa. Plant Dis. 78:309-312.

38. Wingfield, M. J., Hammerbacher, A., Ganley, R. J., Steenkamp, E. T. Gordon, T. R., Wingfield, B. D., and Coutinho, T. A. 2008. Pitch canker caused by Fusarium circinatum - a growing threat to pine plantations and forests worldwide. Australas. Plant Pathol. 37:319-334.

39. Wingfield, M. J., Jacobs, A., Coutinho, T. A., Ahumada, R., and Wingfield, B. D. 2002a. First report of the pitch canker fungus, Fusarium circinatum, on pines in Chile. Plant Pathol. 51:397-397.

40. Wingfield, M. J., Roux, J., Coutinho, T. A., Govender, P., and Wingfield, B. D. 2002b. Plantation disease and pest management in the next century. S Afr. For. J. 190:67-71

41. Yiasoumi, Y. 2005. Water disinfecting techniques for plant pathogen control. Int. Plant Propagat. Soc. Comb. Proc. 55:138-141.

42. Zoffoli, J. P., Latorre, B. A., Daire, N., and Viertel, S. 2005. Effectiveness of chlorine dioxide as influenced by concentration, $\mathrm{pH}$, and exposure time on spore germination of Botrytis cinerea, Penicillium expansum and Rhizopus stolonifer. Cien. Invest. Agrar. 32:142-148. 